\title{
Types of the Amphibian and Reptilian Genera Proposed by Laurenti in 1768 \\ By Leonhard Stejneger
}

I INNAEUS in his Systema Naturae, both the tenth edition (1758) and the L twelfth (1766), included in the class Amphibia three orders which he named, Reptiles, Serpentes and Nantes. His contemporaries and subsequent authors nearly unanimously removed the latter group from the amphibians and added it to the fishes. In the remaining two orders he recognized 10 genera as follows:

\begin{tabular}{|c|c|c|c|}
\hline \multicolumn{2}{|c|}{ REPTIESS } & \multicolumn{2}{|r|}{ SERPENTES } \\
\hline Testudo & 3 Lacerta & 1 Crotalus & 3 Coluber \\
\hline 2 Draco & $4 \operatorname{Ran} a$ & $2 B o a$ & 4 Anguis \\
\hline
\end{tabular}

When it is realized that under Lacerta he included both the crocodiles and the salamanders, it must be admitted that the arrangement was very artificial. It was, nevertheless, accepted by most writers until the end of the eighteenth century.

Two years after the publication of the 12th edition of the Systema Naturae-there appeared in Vienna a small book (216 octavo pages) entitled:

Josephi Nicolai / Laurenti / Austriaci Viennensis /

Specimen / Medicum, / exhibens / Synopsin Reptilium /

Emendatam / cum experimentis circa venena / et

Antidota Reptilium Austriacorum. / [Vignette]-Viennæx, /

Typ. Joan. Thom. Nob. de Trattnern, / Cæs. Reg. Aulæ

Typogr, et Bibliop. / -1768 .

The book falls into two quite distinct parts, the first, embracing 110 pages, a systematic descriptive part simply headed "Classis Reptilium" (p. 19), and a second part (pp. 111-214) with the following heading: "Historia Reptilium Austriacorum, continens singulae speciei differentiam, descriptionem et instituta circa venena experimenta." It is accompanied by five folded copper-engraved plates with 19 figures representing Austrian amphibians and reptiles.

Only the first part interests us here. In it Laurenti ${ }^{1}$ divides the Class Reptilia into three orders, Salientia, Gradientia and Serpentia, and these three again into 35 genera, some of which had already been indicated by Gronovius. The order Salientia contains the toads and frogs; the Serpentia embraces snakes and legless lizards and amphibians; and although the Gradientia still includes the salamanders, lizards and crocodiles, the arrangement is a distinct advance on that of Linnaeus. The great improvement consists in the large number of new genera adopted. Nevertheless I know of a single author only among his early successors who accepted his classification in practically all its details, including his generic nomenclature, viz., Aug. Joh. Georg. Carl Batsch in his two-volume "Versuch einer Anleitung zur Kenntnisz und Geschichte der Thiere und Mineralien."'

\footnotetext{
1 The real author is said to have been Winterl, who later became professor of Chemistry at Pest, Hungary, and who, because of financial difficulties during bis student days, sold the manuscript to Laurenti (Fejérváry, Verh. Zool. Bot. Ges. Wien, 1917: 175).

"Jena, 1788. Batsch, however, calls the class Amphibia, and for the four orders, or "families" as he calls them, he uses the iname Testudines, Batrachi, Iacertae and Serpentes. Laurenti, it is true, did not mention the chelonians, but that may have been because he had no changes or additions to the Linnean system to propose, as it is not likely that he considered them as belonging to some other "class."
} 
With the increasing improvement in herpetological science towards the end of the century which made necessary the splitting up of the Linnaean genera, Laurenti's work was more or less-in many cases apparently intentionally - passed over in silence. Some of his generic names were applied in a different sense, other generic divisions which could not be ignored were given new designations, with the result that in recent years, when the strict application of the law of priority has necessitated the acceptance of the Laurentian names, considerable confusion has arisen as to the correct application of the latter. Generic type species have in many cases been erroneously designated for his generic names, others have remained type-less till the present time.

In order to correct previous errors ${ }^{3}$ in such type designations and to prevent future ones the following survey was undertaken.

\section{Genus I: Prpa, p. 24}

Type Pipa americana, p. 25, both by monotypy and tautotypy, the species having for synonym Linnaeus' Rana pipa (Syst. Nat., 10 ed., vol. 1, 1758: 210).

Genus II: BuFo, p. 25

Contains 13 species, among them Bufo vulgaris, p. 28, a synonym of Linnaeus' Rana bufo (Syst. Nat., 10 ed., vol. 1, 1758: 210), which therefore is the genotype of Bufo Laurenti by. absolute tautonymy.

Genus III: RaNA, p. 29

A Linnaean generic name (Rana Linnaeus, Syst. Nat., 10 ed., vol. 1, 1758 ; p. 210). Genotype subsequently designated by Fleming (Philos. Zool., vol. 2, 1822: 304): "The common frog" = Rana temporaria Linnaeus ( $o p$. cit.: 212), of which Laurenti's Rana muta, p. 20, is a synonym.

Genus IV: HyLA, p. 32

This generic term was applied by Laurenti to nine nominal species, several of which are of disputed identity. The name $H y l a$ was for the first time applied by him to the tree frogs and is not found in any of the previous zoological literature either as a generic or as a specific appellation. The genotype therefore depends on subsequent designation. Fitzinger in 1843 (Syst. Rept.: p. 30) designated Hyla boans of Daudin as the type, but as this species is not included among Laurenti's original nine species, the designation is void. As a matter of fact $I$ have found none of these definitely and specifically denoted as type until 1907 when in the Herpetology of Japan (p. 75) I so designated Laurenti's Hyla viridis (p. 33) which is a synonym of Linnaeus' Rana arborea (Syst. Nat., 10 ed., vol. 1, 1758: 213).

\section{Genus V: Proteus, p. 35}

Laurenti under this genus includes three species, viz., Proteus raninus (p. 36) from Surinam; Proteus tritonius (p. 37) from the Etscher Alp, Austria; and Proteus anguinus (p. 37) from the Zirknits Lake, Carniola. $\mathrm{He}$ characterized the genus as having lungs and gills at the same time.

Curiously enough he placed the Proteus ranimus in Ordo I, Salientia, and the two other species in Ordo II, Gradientia, because the former has "Pedes postici saltatorii," while the latter are provided with "pedibus posticis gradientibus."

3 "Errors" or perhaps better, "unconformities" with the present International Rules of Zoological Nomenclature. 
Proteus raninus was soon recognized as the larva of Linnaeus' Rana paradoxa, and Proteus tritonizis as that of Laurenti's own Triton alpestris. Merrem, in 1820 (Tent. Syst. Amph.: 188), leaving the genus practically monotypic, substituted Hypochthon for Proteus under the erroneous impression that Proteus was preoccupied, thus establishing $P$. anguinus as the genotype of Proteus under the substitute name Hypochthon laurentii (Int. Code, art. 30, II f).

\section{Genus VI: Triton, p. 37}

Comprises 11 species. Of these Triton cristatus Laurenti (p. 39) was designated in 1843 by Fitzinger (Syst. Rept.: 34 ) as the genotype. Rafinesque in 1815 (Anal. Nat.: p. 78) substituted Triturus for Laurenti's Triton because the latter was preoccupied by Linnaeus for a mollusk. T. cristatus, therefore, becomes the genotype for Triturus (Int. Code, art. 30, II. f.)

Genus VII: Salamandra, p. 41

In this genus Laurenti recognized 6 species, but as his Salamandra maculosa (p. 42) equals Linnaeus' Lacerta salamandra (Syst. Nat., 10 ed., vol. 1, 1758: p. 204) it becomes the genotype by tautonymy.

Genus VIII: Caudiverbera, p. 43 [err. typ. 34]

Laurenti includes two species in this genus, $C$. aegyptiaca based on "Seba II. 103, 2." and C. peruviana based on "Feuillée Diarium Bot. II. 319." As the latter is the same as Lacerta caudiverbera Linnaeus (Syst. Nat., 10 ed., vol. 1, 1758: p. 200) it becomes the genotype.

\section{Genus IX: Geisko, p. 43 [err. typ.: 34]}

Of the three species included in this genus Gekko verticillatus (p. 44) is only another name for Linnaeus' previous Lacerta gecko (Syst. Nat., 10 ed., vol. 1, 1758: 205) which therefore is the type of the genus by tautonymy.

\section{Genus X: Chamaeleo, p. 45}

Laurenti is the first author to establish the genus Chamaeleo, except for Gronovius' Chamaeleon (1753, Zoophyl.: 12) which has been made unavailable by Opinion 89 of the International Commission on Zoological Nomenclature.

In his Chamaeleo Laurenti includes six named species, of which five appear to be based on figures in the first volume of Seba's Thesaurus, and one on a specimen in the Museum Turrianum, viz.:

p. 45. Chamaeleo mexicanus, based on Seba I. 82. 1.

Chamaeleo parisiensium, on Seba I. 82. 2 \& 4 \& 5 .

p. 46. Chamaeleo zeylanicus, on Seba I. 82. 3.

Chamaeleo africanus, on Seba I. 43. 4 (generally accepted as a misprint for 83. 4).

Chamaeleo candidus, on specimen "in Museo Turriano."

Chamaeleo bonae spei, on Seba I. 83. 5.

One of the species represented by one of these names must be the type of the genus Chamaeleo of Laurenti.

The first step in determining the type according to Article 30 of the International Code of Zoological Nomenclature is to ascertain whether the case is one of type acceptation solely upon the basis of the original publica- 
tion. As noither original type designation, nor monotypy is involved, there remains to be determined whether the genus "contains among its original species one possessing the generic name as its specific name, either as a valid name or synonym," in which case "that species or subspecies becomes ipso facto type of the genus."

Since the name chamaeleo does not occur as the trivial name of any of Laurenti's species, the question arises whether one of them "possesses" that name as a synonym, to answer which it becomes necessary to examine into the status of his species.

The speries of which Laurenti has examined a specimen and which he called $C$. candidus is so poorly characterized that it must for ever remain unidentified. The few authors who have attempted to do so have guessed that it was a bleached specimen of the common chameleon, but nobody has proposed to use the name and it may safely be left out of consideration here.

All the others of the Laurentian names are based on Seba's figures on plates 82 and 83 of his first volume. Unfortunately they are so poor, that their identification is mostly very uncertain and the various interpreters have disagreed in most instances.

In studying Seba's figures with a view to their identification with the known species of chameleons, we must not expect to make such positive determinations as would compel us to substitute Laurenti's specific names for later ones which are based on incontrovertible evidence. The original specimens from which the engravings were made undoubtedly belong to the genus Chamaeleo as generally restricted, and it will be satisfactory if we can point out one of them as fairly representing the Linnaean species Lacerta chamaeleo in such a way that the Laurentian species may be said to "possess" the Linnaean name as a synonym. Fortunately, Seba's plate 82, figs. 2 (adult) and 4, 5 (young), the basis of Chamaeleo parisiensium Laurenti, fill that requirement. The figures represent a typical chameleon with a raised but not very high casque, no enlarged tubercles on the body; no dorsal crest; slightly enlarged granules on the median line of the throat; no ventral crest; no tarsal spur. As Linnaeus specifically quotes these figures under his Lacerta chamaeleon, I have no hesitation in declaring that $C$. parisiensium is the genotype of Chamaeleo Laurenti by tautonymy. The name of the common chameleon, therefore, becomes Chamaeleo chamaeleon (Linnaeus) by tautonymy. It can have but little weight that Boulenger (Cat. Liz. Brit. Mus., vol. 2: 443) in the synonymy of $C$. vulgaris quotes $C$. parisiensium with a query. All previous authors have unhesitatingly accepted the above identification.

\section{Genus XI: Iguana, p. 47}

Ten species. Type by tautonymy Lacerta iguana Linnaeus (Syst. Nat., 10 ed., vol. 1, 1758: 206), which equals Iguana tuberculata Laurenti, genotype.

\section{Genus XII: Basiliscus, p. 50}

Basiliscus americanus (p. 50) is the only species included, hence becomes genotype by monotypy, as well as by tautonymy as it is synonymous with Lacerta basiliscus Linnaeus (Syst. Nat., 10 ed., vol. 1, 1758: 206). 
Genus XIII: Draco, p. 50

Laurenti includes two species in this Linnaean genus (Syst. Nat., 10 ed., vol. 1, 1758: 199), D. major and D. minor both considered as belonging to the same species and synonymous with Draco volans Linnaeus, the genotype.

Genus XIV: CoRdyuUs, p. 51

Gronovius (Zoophyl., 1763: 13) had already made Lacerta cordylus Linnaeus (Syst. Nat., 10 ed., vol. 1, 1758: 202) the monotype and tautotype of the genus Cordylus, but the name is unavailable by the action of the International Commission of Zoological Nomenclature (Opinion 89).

Laurenti reintroduced the name but included four more species. However, as his Cordylus verus (p. 52) is a synonym of Lacerta cordylus of Linnaeus, this species remains the genotype of Cordylus by tautonymy.

Merrem's monotypic Zonurus (Nat. Syst. Amph., 1820: 57) thus becomes a synonym, and the proper name of his Zonurus cordylus is Cordylus cordylus (Linnaeus).

Genus XV: Crocodyuus, p. 53

The genotype is Crocodylus "niloticus = Lacerta crocodilus" Linné in part," by subsequent designation of Stejneger and Barbour (Check List of North American Amphibians and Reptiles, 1 ed., 1917: 41).

For a full discussion of the question see the article on "Crocodilian Nomenclature" by Stejneger in CopeIA (No. 3, October 15, 1933: 117-120).

Genus XVI: ScINcus, p. 55

Genotype by tautonymy Scincus officinalis which is Linnaeus' Lacerta scincus (Syst. Nat., 10 ed., vol. 1, 1758: 205; 12 ed., vol. 1, 1766: 365).

Genus XVII: Stellio, p. 56

Stellio saxatilis Laurenti (p. 57) was designated by Stejneger in 1933 as the genotype. The designation was made in a letter to Malcolm A. Smith (published in the Journal of the Bombay Natural History Society, vol. 35, No. 3: 618-619), which was an abstract from the present manuscript. It is here given with a few slight modifications caused by Dr. Smith's annotations.

Laurenti's Stellio, the first application of this name to various genera of lizards, includes 8 nominal species, none of which can be accepted as type "solely upon the basis of the original publication" (Intern. Code, art. 30, I, a-d). As none of the 8 species are excluded from consideration in determining the type (same art., II, e) and as nobody apparently has selected as yet a type for Laurenti's Stellio (in contradistinction to Stellio Schneider, 1792, or Stellio Latreille, 1802) it seems that I am at liberty to designate the type (same art., g). None of the Recommendations of the Code, appended to Art. 30, has any direct bearing on the peculiarities of this case.

The 8 species named by Laurenti were all unknown to him except from Seba's figures and descriptions. Of these there is no difficulty in identifying Stellio saurus, S. salvator and $S$. salveguardia as belonging to the genus Varanus, and S. thalassinus has also been referred to it by MaIcolm Smith. Authors likewise agree that Laurenti's Stellio punctatus is a skink, viz., Linnaeus' Lacerta punctata ( $=$ Eumeces punctatus of Duméril and Bibron $=$ Lygosoma punctatum of Boulenger).

If Laurenti's Stellio were to be restricted to any of these species it would 
supplant either Varanus or Eumeces or Lygosoma respectively, as Stellio is the older name, a calamity to be prevented if possible.

There remain 3 species, however, the identification of which is more or less doubtful, viz.:

1. Stellio saxatilis (Seba, II, 79. 4).

2. Stellio tessellatus (Seba, I, 76. 2) "Habitat in Virginia."

3. Stellio viridis (Seba, I, 75. 2) "Habitat in Virginia."

The first one Merrem (Syst. Amph. 1820: 52) renamed Agama tetradactyla because distinguished by having 4 toes on forefeet. The fourtoed Stellio or Agama has remained a mystery ever since and may be considered unidentifiable. The second and third he considered identical and renamed the compound Lacerta longicauda.

No one has recognized the Agama or the Lacerta since. An inspection of Seba's figures shows that Merrem's guesses were not fortunate. In the first place, Nos. 2 and 3 can not well belong to the same genus, as the former has small head scales and a serrated upper edge to the tail, and the latter has large head shields and no serrated upper tail edge. The former may be some iguanoid, while the latter shows a certain resemblance to Tupinambis teguixin.

Under these circumstances, rather than to cause a wholesale mixup of names current for a century, it seems the better policy to select as the type one of the unidentifiable names, a procedure calculated to lay the specter of Stellio becoming active again in herpetological nomenclature. With this in view I designate Stellio saxatilis Laurenti the type of Stellio Laurenti.

Genus XVIII: Seps, p. 58

In this genus Laurenti included 17 species, of which seven were based on specimens observed by himself, the others mostly on Seba's figures. All of those examined by himself belong to the genus Lacerta as now commonly accepted, and many of the others, in so far as they can be identified, to such teiid genera as Ameiva and Cnemidophorus.

None of the species included possess Seps as a specific name or among their synonyms, and as far as I have been able to ascertain, nobody has designated a type for Laurenti's Seps.

The generic term Seps has been variously applied by subsequent writers, beginning with Daudin (1803) to lygosomid groups having Lacerta seps Linnaeus (Syst. Nat., 10 ed., vol. 1, 1758: 204) for type, a species unknown to, or at least not included by Laurenti. The result has been that the name Seps has become a source of confusion which can only be avoided by herewith designating Laurenti's Seps caerulescens (Syn. Rept., 1768: 62, pl. 1, fig. 3) as the type of his genus Seps. As this is a synonym of Linnaeus' Lacerta agilis, the type of Lacerta Linnaeus, the name Seps is effectually submerged.

Genus XIX: Chalcides, p. 64

Contains two species: "Chalcides tridactyla Columnae. Ecphras. 36" and "Chalcides pinnata. Seba II. 58. 7. \& 8." The former is Linnaeus' Lacerta chalcides (Syst. Nat., 10 ed., vol. 1, 1758: 209) and is consequently the genotype by tautonymy. 
Genus XX: Caecruia, p. 65

This is a Linnaean genus (Syst. Nat., 10 ed., vol. 1, 1758: 229) which has for type Linnaeus' $C$. tentaculata in part. The designation was made in 1843 by Fitzinger (Syst. Rept.: 34) who mentions C. lumbricoidea Daudin as the type, but this species is one of the components of Linnaeus' original C. tentaculata.

Genus XXI: Amphisbaena, p. 65

Another Linnaean genus (Syst. Nat., 10 ed., vol. 1, 1758:229) with genotype Amphisbaena fuliginosa Linnaeus (loc. cit.) designated by Fleming (Philos. Zool., vol. 2, 1822: 29), and by Fitzinger (Syst. Rept., 1843: 22).

Genus XXII: AnguIs, p. 67

The status of this genus is identical with that of the last two established by Linnaeus (Syst. Nat., 10 ed., vol. 1, 1758:227), type by designation of Fleming (Philos. Zool., vol. 2, 1822: 289), and by Fitzinger (Syst. Rept., 1843: 23), Anguis fragilis Linnaeus.

\section{Genus XXIII: NatrIX, p. 73}

Of the 22 species included by Laurenti in this genus, his Natrix vulgaris (p. 75) is the genotype both by tautonymy (Coluber natrix Linnaeus, Syst. Nat., 10 ed., vol. 1, 1758: 220) and by subsequent designation (Fleming, Philos. Zool., vol. 2, 1822: 29).

\section{Genus XXIV: Cerastes, p. 81}

Under this generic term Laurenti described no less than 11 species, none of which includes the name Cerastes as a specific name; none is named specifically typicus or typus; nor is any of the included species doubtfully referred to it or treated as a species inquirenda. Finally, as far as $I$ have been able to ascertain, no subsequent author has as yet designated a genotype of Cerastes Laurenti 1768. It is therefore my pleasure to designate Laurenti's Cerastes candidus as the type, thus making it a synonym of Naja Laurenti 1768: 90 (type by tautonymy Coluber naia Linnaeus) as Cerastes candidus is properly identified with the previously named Coluber haje Linnaeus (Syst. Nat., 10 ed., vol. 1, 1758: 225). By this action the generic name Cerastes which had caused much trouble in herpetological nomenclature is practically eliminated. The designation of any other of the 11 Laurentian species would have replaced some well established generic name as will be seen from the following enumeration:

C. severus is the designated type of Xenodon Fitzinger 1826

C. plicatilis is the designated type of Pseudoeryx Fitzinger 1826

C. aurora is the designated type of Lamprophis Fitzinger 1843

C. rhombeatus is the designated type of Psammophylax Fitzinger 1843

C. agilis is the designated type of Erythrolamprus Wagler (Fitzinger 1843)

C. lacteus is the designated type of Elaps Fleming 1822

C. nebulatus is the designated type of Sibon Fitzinger 1843

C. cobella is the designated type of Liophis Wagler (Fitzinger 1843)

C. coronatus is the monotype of Spilotes Wagler 1830

C. mexicanus belongs in Spilotes Wagler 1830

C. candidus belongs in Naja Laurenti 1768

Genus XXV: CoRONella, p. 84

The first definite designation of a type for Laurenti's Coronella seems to have been made by Cope in 1860 (Proc. Acad. Nat. Sci. Philadelphia, 1860: 
245) who selected Coronella austriaca (p. 84) and whose choice has been generally accepted.

Genus XXVI: BoA, p. 88

Linnaeus in 1758 (Syst. Nat. 10 ed., vol. 1: 214) established the genus Boa which among others included the species Boa constrictor Linnaeus. Laurenti in 1768 by creating the genus Constrictor (p. 106) and including in it a species having $B o a$ constrictor as a synonym, made the latter the genotype of his genus Constrictor, while at the same time retaining the generic term $B o a$ for the three nominal species $B$. thalassina, $B$. aurantiaca and $B$. exigua, all three of which are synonyms of Linnaeus' Boa canina (Syst. Nat., 10 ed., vol. 1, 1758: 215) which thus virtually becomes the monotypic genotype of the restricted genus $B o a$ in conformity with Opinion 5 of the International Commission of Zoological Nomenclature (1910: 7).

Genus XXVII: Dipsas,'p. 89

The genotype is Dipsas indica Laurenti (p. 90) which is the only species included.

Genus XXVIII: NAJA, p. 90

Genotype by tautonymy and practically also by monotypy, as all the 6 nominal species included by Laurenti are synonyms of Coluber naja Linnaeus (Syst. Nat., 10 ed., vol. 1, 1758: 221).

\section{Genus XXIX: Caudisona, p. 92}

Fleming, in 1822 (Philos. Zool., vol. 2: 294) designated as type C. horridus which corresponds to Laurenti's Caudisona durissus, based on Catesby's pl. 41. The latter is not Linnaeus' Crotalus durissus.

Genus XXX: Coluber, p. 94

The genus was established in 1758 (Syst. Nat., 10 ed., vol. 1: 216) by Linnaeus and Coluber constrictor Linnaeus was designated by Fitzinger in 1843 (Syst. Rept.: 26) as the type.

Genus XXXI: VIPERA, p. 99

Fleming, in 1822 (Philos. Zool., vol. 2: 295) designated $V$. berus as the type of the genus Vipera, but as this species was not included by Laurenti the designation is void. As a matter of fact, Laurenti had included berus in the genus Coluber. On the other hand, Fitzinger, in 1843, designated Vipera redii as the type. This being Laurenti's Vipera francisci redi which equals Coluber aspis Linnaeus, the latter becomes the genotype of Vipera.

Genus XXXII: CoBra, p. 103

Laurenti's genus embraces three nominal species, viz., C. clotho, C. lachesis and $C$. atropos. The two former are based on figures by Seba (Seba II. 93 and 94.2 ) and are practically unidentifiable. Moreover, by most authors they have been considered probable synonyms of the third species, Linnaeus' Coluber atropos. This view makes the latter type by monotypy. But, in addition, Fitzinger in 1826 (Neue Classif. Rept.: 33) established Cobra for Daudin's Vipera atropos, which thus becomes type of the genus by subsequent designation.

Cobra is consequently the proper name for the genus commonly known as Bitis. 
Genus XXXIII: Aspis, p. 105

The question of the genotype of this species has been discussed by me on a previous occasion (Medd. Zool. Mus. Kristiania, No. 2, 1922: 7). I still hold that "the type of Aspis, according to the interpretation of the International Rules, Art. 30, I, d, by the International Commission on Z0ological Nomenclature, as expressed in their Opinion 16, is clearly Aspis cleopatrae. Laurenti in quoting Lucanus' Aspis as applying to the species Aspis cleopatrae has fixed the latter as the type by tautonymy, whether interpreting Lucanus correctly or incorrectly."

\section{Genus XXXIV: CONSTRICTOR, p. 106}

The genus comprises 5 nominal species, three of which, viz., $C$. formosissimus, $C$. rex serpentum and $C$. auspex, all based on Seba's figures, are considered conspecific and synonymous with Linnaeus' Boa constrictor (Syst. Nat., 10 ed., vol. 1: 215) which thus becomes the genotype by tautonymy.

Genus XXXV: Laticauda, p. 109

Of the two nominal species included, L. scutata is a synonym of Linnaeus' previous Coluber laticaudatus (Syst. Nat. 10 ed., vol. 1, 1758: 222). This is practically tautonymy, but to malse doubly sure I designated L. scutata (Herpet. Japan: 402) in 1907, as the type of Laticauda.

U. S. National Museum, Washington, D. C.

Description of a New Pbyllodactylus from Mexico, with Remarks on the Status of P. tuberculosus

\section{By Walter Mosauer}

$T^{N}$ the course of an herpetological expedition ${ }^{1}$ to Mexico, in 1935, the writer 1 secured two specimens of an apparently undescribed gecko of the genus Phyllodactylus. Both specimens were collected among large boulders in the tropical forest near Tierra Colorada, Guerrero. They differ strikingly from the local population of Phyllodactylus tuberculosus which is common in the some locality.

\section{Phyllodactylus delcampi ${ }^{2}$, sp. $\mathrm{n}$.}

Type Specimen.-No. 41238, M.C.Z.; collected at Tierra Colorada, Guerrero, August, 1935, by W. Mosauer.

Paratype.-No. 42139, M.C.Z. Same data.

Diagnosis.-A large Phyllodactylus, with 12 to 13 dorsal longitudinal

II wish to express my sincere gratitude to the authorities of the University of California for the financial support, in the form of a research grant, of the expedition during which the material discussed was collected, and to the Mexican authorities for the many courtesies extended throughout the course of the expedition. I am also deeply indebted to Dr. Edward $\mathrm{H}$. Taylor of "the University of Kansas for information and the loan of literature, such as a transcript of Wiegmann's paper, to Mr. Joseph R. Slevin of the California Academy of Sciences, to Mr. L. M. Klauber of the Zoological Society of San Diego, to Dr. Doris Cochran of the U.S. National Museum, and to Dr. F. S. Wood of the Los Angeles Junior College, for the loan of specimens of $P$. tuberculostus.

2 Named for Sefior Rafael Martin del Campo, director of the Natural History Museum of Mexico, whose researches are contributing much to our knowledge of the herpetology of his native country. He has also very kindly aided visiting colleagues in the purstiit of their studies. 